\title{
FAKTOR-FAKTOR YANG MEMPENGARUHI ISLAMIC SOCIAL REPORTING PERUSAHAAN-PERUSAHAAN YANG TERDAFTAR PADA INDEKS SAHAM SYARIAH INDONESIA (ISSI) TAHUN 2014-2016
}

\author{
Eka Susanti ${ }^{1)}$, Puji Nurhayati ${ }^{2)}$ \\ Program Studi Akuntansi, Universitas PGRI Madiun \\ kopieka1@gmail.com \\ nurhayatipuji90@gmail.com
}

\begin{abstract}
This study aims to obtain empirical evidence on the analysis of factors affecting Islamic Social Reporting (ISR). Factors used include company size, profitability, industry type, and as an additional variable that is sharia securities. The measurement of Islamic Social Reporting (ISR) is based on the category of Islamic reporting to measure the Index ISR viewed from the company's annual report. The population in this study are all companies listed in Indonesia Sharia Shares Index (ISSI) in 2014-2016. Sampling method used in this research is purposive sampling method. The total sample used in this study as many as 10 companies. Data analysis was done by classical assumption test and hypothesis testing by multiple regression method. The results of this study indicate that the company size factor, Profitability No significant positive effect on ISR in Indonesia. While the type of industry, Securities have a significant effect on ISR in Indonesia.

Keyword : Islamic Social Reporting, List of Sharia Securities, ISR Index and company's characteristic
\end{abstract}

Penelitian ini bertujuan untuk memperoleh bukti empiris mengenai analisis faktor-faktor yang mempengaruhi Islamic Social Reporting (ISR). Faktorfaktor yang digunakan antara lain ukuran perusahaan, profitabilitas, tipe industri, dan sebagai variabel tambahan yaitu surat berharga syariah. Pengukuran Islamic Social Reporting (ISR) didasarkan pada kategori islamic social reporting untuk mengukur ISR Indeks yang dilihat dari laporan tahunan perusahaan. Populasi dalam penelitian ini adalah seluruh perusahaan yang terdaftar di Indeks Saham Syariah Indonesia (ISSI) pada tahun 2014-2016. Metode sampling yang digunakan dalam penelitian ini adalah metode purposive sampling. Total sampel yang digunakan dalam penelitian ini sebanyak 10 perusahaan. Analisis data dilakukan dengan uji asumsi klasik dan pengujian hipotesis dengan metode regresi berganda. Hasil dari penelitian ini menunjukkan bahwa faktor Ukuran Perusahaan, Profitabilitas Tidak berpengaruh positif signifikan terhadap ISR di Indonesia. Sedangkan Tipe industri, Surat berharga berpengaruh secara signifikan terhadap ISR di Indonesia.

Kata Kunci : Islamic Social Reporting (ISR), ukuran perusahaan, profitabilitas, tipe industri, dan surat berharga syariah.

\section{PENDAHULUAN}

Isu mengenai tanggung jawab sosial perusahaan atau CSR (Corporate Social Reporting) kian menjadi sorotan penting dalam beberapa dekade terakhir. Hal ini tidak terlepas dari adanya konsep CSR yang merupakan inti dari etika bisnis bagi tiap perusahaan. Isu mengenai tanggung jawab sosial perusahaan atau CSR (Corporate Social Responsibility) ini telah banyak diterapkan di negara-negara maju maupun negara berkembang. Setiap perusahaan harus membangun tanggung jawab sosial atau corporate social responsibility(CSR). Berkembangnya CSR dalam ekonomi Islam juga turut meningkatkan perhatian masyarakat terhadap lembaga atau institusi syariah. Meningkatnya perhatian masyarakat mengindikasikan bahwa kebutuhan masyarakat terhadap 
lembaga atau instansi syariah semakin besar dari waktu ke waktu. Pasar modal syariah sebagai lembaga dan profesi yang berperan penting dalam meningkatkan pangsa pasar efek-efek syariah pada perusahaan-perusahaan ingin berpartisipasi dalam pangsa pasar syariah di Indonesia. Kini konsep CSR tidak hanya berkembang di ekonomi konvensional, melainkan juga berkembang dalam ekonomi Islam. Konsep CSR dalam Islam erat kaitannya dengan perusahaanperusahaan yang menjalankan kegiatan bisnis sesuai dengan konsep syariah yang diharapkan perusahaan tersebut dapat melakukan tanggung jawab sosial perusahaan secara islami. Berkembangnya CSR dalam ekonomi islam juga turut meningkatkan perhatian masyarakat terhadap lembaga atau institusi syariah. Pasar modal sebagai lembaga dan profesi yang berkaitan dengan efek dalam hal ini adalah pasar modal syariah berperan penting dalam meningkatkan pangsa pasar efek-efek syariah pada perusahaan-perusahaan yang ingin berpartisipasi dalam pasar modal syariah.

Di Indonesia, perkembangan pasar modal syariah diawali dengan dibentuknya Jakarta Islamic Index (JII). Jakarta Islamic Index ini hanya terdiri dari 30 saham syariah yang tercatat di Bursa Efek Indonesia (BEI). Namun, munculnya Indeks Saham Syariah Indonesia (ISSI) akan menjadi acuan bagi investor untuk berinvestasi di saham syariah sekaligus menggambarkan kinerja seluruh saham syariah yang tercatat di BEI serta membantu menjelaskan kesalahpahaman masyarakat yang beranggapan bahwa saham syariah hanya terdiri dari 30 saham yang masuk dalam JII (www.idx.co.id).

Othman dan Thani (2010) memaparkan bahwa perkembangan pasar modal syariah yang begitu cepat membuat perusahaan-perusahaan yang masuk pada Daftar Efek Syariah diekspektasikan untuk menyajiikan suatu dimensi religi dalam pengungkapan laporan tahunan yang bertujuan untuk memberi manfaat bagi para pemangku kepentingan muslim. Oleh karena itu, dibutuhkan acuan (guideline) untuk mengukur sejauh mana perusahaan-perusahaan yang terdapat pada Daftar Efek Syariah membuat laporan tanggung jawab sosial yang turut menyajikan aspekaspek religi dalam laporan tahunan. Othman et al. (2009) mengembangkan indeks pengungkapan yang relevan dengan hal-hal yang telah disebutkan sebelumnya pada Islamic Social Reporting (ISR) Index. ISR pertama kali dikemukakan oleh Haniffa (2002) lalu dikembangkan secara lebih ekstensif oleh Othman et al. (2009) di Malaysia. Haniffa (2002) mengungkapkan bahwa adanya keterbatasan dalam pelaporan sosial konvensional sehingga ia mengemukakan kerangka konseptual Islamic Social Reporting berdasarkan ketentuan syariah yang tidak hanya membantu pengambilan keputusan bagi pihak muslim melainkan juga untuk membantu perusahaan dalam melakukan pemenuhan kewajiban terhadap Allah Subhanaahu wa Ta'ala dan masyarakat.

Penelitian ini bertujuan untuk menganalisis faktor-faktor yang mempengaruhi Islamic Social Reporting (ISR) perusahaan perusahaan yang terdapat pada Indek saham Syariah tahun 2014-2016. 
METODE PENELITIAN

\section{Populasi dan Sampel}

Populasi dalam penelitian ini adalah perusahaan yang terdaftar pada Indeks Saham Syariah Indonesia periode 2014-2016. Dalam penelitian ini jumlah sampel yaitu 138 Perusahaan Pemilihan sampel dalam penelitian ini dilakukan dengan metode purposive sampling.

\section{Jenis dan Sumber Data}

Data Pada penelitian ini, teknik pengumpulan data yang digunakan adalah teknik dokumentasi Menurut Sugiyono (2013) "dokumen merupakan catatan peristiwa yang sudah berlalu. Dokumen bisa berbentuk tulisan, gambar, atau karya-karya monumental dari seseorang."

\section{Teknik Analisis Data}

Data yang terkumpul melalui hasil dokumentasi dengan strategi arsip diseleksi dan diedit menurut kebutuhan kemudian dihitung statistik dengan menggunakan program SPSS Release 22.0. dengan analisis regresi linier berganda. Persamaan regresi linear berganda dalam penelitian ini adalah:

$$
\operatorname{ISR}_{i, \mathrm{t}}=\alpha+\beta_{1}(\mathrm{SIZE})_{\mathrm{i}, \mathrm{t}}+\beta_{2}(\mathrm{ROA})_{\mathrm{i}, \mathrm{t}}+\beta_{3}(\mathrm{TIPE})_{\mathrm{i}, \mathrm{t}}+\beta_{4}(\mathrm{SBS})_{\mathrm{i}, \mathrm{t}}+\varepsilon_{\mathrm{i}, \mathrm{t}}
$$

Keterangan notasi:

$\begin{array}{ll}\text { ISR }_{\mathrm{i}, \mathrm{t}} & : \text { Islamic Social Reporting perusahaan i pada waktu t } \\ \text { SIZE }_{\mathrm{i}, \mathrm{t}} & : \text { ukuran perusahaan perusahaan i pada waktu t. } \\ \text { ROA }_{\mathrm{i}, \mathrm{t}} & : \text { profitabilitas perusahaan i pada waktu t } \\ \text { TIPE }_{\mathrm{i}, \mathrm{t}} & : \text { tipe industri perusahaan i pada waktu t } \\ \text { SBS }_{\mathrm{i}, \mathrm{t}} & : \text { Surat Berharga Syariah perusahaan i pada waktu t } \\ \alpha & : \text { konstanta (constant) } \\ \beta_{1}-\beta_{4} & : \text { koefisien regresi variabel bebas 1 sampai dengan } 4 \\ \varepsilon_{\mathrm{i}, \mathrm{t}} & : \text { Error (kesalahan pengganggu) }\end{array}$

Hipotesis diuji pada tingkat hipotesis diterima berarti variabel signifikansi 5\%. Kriteria penerimaan tersebut memang mempengaruhi atau penolakan hipotesis akan pemilihan metode akuntansi didasarkan pada nilai p-value. persediaan. Tetapi jika tidak berarti Apabila p-value $>5 \%$ maka hipotesis variabel tersebut tidak berpengaruh ditolak. Sebaliknya apabila $\mathrm{p}$-value $<\quad$ terhadap pemilihan metode akuntansi 5\% maka hipotesis diterima. Apabila persediaan 


\section{HASIL PENELITIAN DAN PEMBAHASAN}

\section{Deskripsi Sampel Penelitian}

\section{Tabel 1}

\begin{tabular}{llc}
\hline No. & \multicolumn{1}{c}{ Karateristik Perusahaan } & Jumlah \\
\hline 1. Jumlah perusahaan non keuangan yang terdaftar pada & 138 \\
Indeks Saham Syariah Indonesia dari tahun 2014-2016 & \\
2. Perusahaan yang tidak terdaftar saham baru ISSI & $(60)$ \\
3. Perusahaan yang tidak menyajikan laporan keuangan & $(54)$ \\
$\begin{array}{l}\text { secara lengkap pada periode tahun 2014-2016 } \\
\text { Perusahaan yang menerbitkan laporan keuangan tahunan } \\
\text { dalam mata uang selain Rupiah }\end{array}$ & $(14)$ \\
Jumlah perusahaan yang menjadi sampel penelitian & $\mathbf{1 0}$ \\
\hline
\end{tabular}
Sumber: Hasil olah penulis

\section{Statistik Deskriptif}

Uji statistik deskriptif dalam penelitian ini digunakan untuk melihat nilai minimum, maximum, mean dan standart deviation. Adapun hasil dari uji statistik deskriptif adalah sebagai berikut :

\section{Descriptive Statistics}

\begin{tabular}{lrrrrr} 
& \multicolumn{2}{c}{ Minimu } & \multicolumn{2}{c}{ Maximu } & Std. \\
& $\mathrm{N}$ & \multicolumn{1}{c}{$\mathrm{m}$} & \multicolumn{1}{c}{ Mean } & Deviation \\
\hline SIZE & 30 & 26.44 & 30.85 & 28.7629 & 1.27564 \\
ROA & 30 & -12.00 & 13.80 & 1.6853 & 6.73142 \\
TIPE & 30 & .00 & 1.00 & .4000 & .49827 \\
SBS & 30 & 1.00 & 3.00 & 1.8000 & .76112 \\
ISR & 30 & .00 & .54 & .3633 & .14153 \\
Valid N & 30 & & & & \\
(listwise) & & & & & \\
Sumber: Hasil olah data & & & & &
\end{tabular}




\section{Pengujian Hipotesis}

Hasil Uji One Sample Kolmogorov-Smirnov

\section{One-Sample Kolmogorov-Smirnov Test}

\begin{tabular}{llr}
\hline & & Unstandardized Residual \\
\hline $\mathrm{N}$ & & 30 \\
Normal Parameters ${ }^{\mathrm{a}, \mathrm{b}}$ & Mean & .0000000 \\
& Std. Deviation & .09397309 \\
Most Extreme & Absolute & .139 \\
Differences & Positive & .085 \\
& Negative & -.139 \\
Kolmogorov-Smirnov Z & & .764 \\
Asymp. Sig. (2-tailed) & & .604 \\
\hline
\end{tabular}

a. Test distribution is Normal.

b. Calculated from data.

Hasil pengujian menggunakan uji Kolmogorov-Smirnov menunjukan bahwa besarnya nilai KolmogorovSmirnov sebesar 0,764 dengan Asymp.Sig. (2-tailed) sebesar 0,604.
Hasil yang diperoleh menunjukan bahwa tingkat signifikan lebih besar dari $0,05 \quad(\alpha>0,05)$, maka dapat disimpulkan data yang di uji terdistribusi normal.

\section{Uji Koefisien Regresi berganda}

\begin{tabular}{llcc}
\multicolumn{4}{c}{$\begin{array}{c}\text { Uji Multikolonieritas } \\
\text { Coefficients }^{\mathbf{a}}\end{array}$} \\
\hline \multicolumn{3}{c}{ Model } & \multicolumn{2}{c}{ Collinearity Statistics } \\
\hline $1 \quad$ Tolerance & VIF \\
\hline & (Constant) & & \\
& SIZE & .634 & 1.576 \\
ROA & .635 & 1.574 \\
& TIPE & .636 & 1.573 \\
SBS & .635 & 1.576 \\
\hline
\end{tabular}

a. Dependent Variable: ISR

Menunjukkan nilai VIF variabel 1,576<10.Nilai tolerance variabel Ukuran Perusahaan (Size) sebesar Ukuran Perusahaan (Size) sebesar $1,576<10$, variabel $R O A$ sebesar $0,634>0,10$, variabel Profitabilitas $1,574<10$, variabel Tipe Industri (ROA) sebesar $0,635>0,10$, variabel sebesar $1.573<10$. variabel surat Tipe Industri (Tipe )sebesar berharga syariah (SBS) sebesar $0,636>0,10$. variabel Surat berharga 
syariah (SBS) sebesar $0,635>0,10$. multikolonieritas antar variabel Dapat disimpulkan bahwa model independen.

regresi tidak terindikasi terjadi

\section{Hasil Uii Heteroskedastisitas}

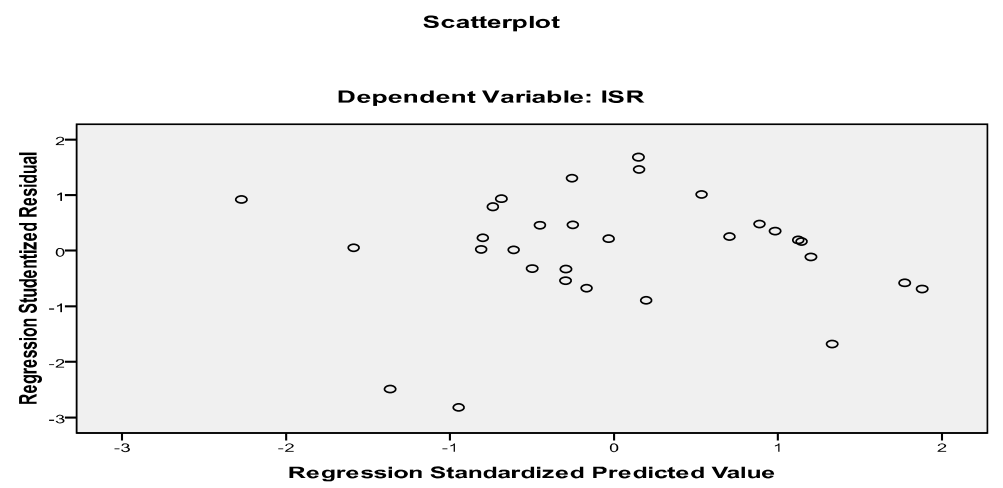

Grafik scater plot menunjukkan bahwa titik-titik pada grafik menunjukkan titik-titik menyebar secara acak dan tidak membentuk pola tertentu serta tersebar baik diatas dan dibawah angka 0 pada sumbu Y, maka dapat disimpulkan bahwa tidak terjadi heteroskedastisitas.

\section{Hasil Uji Autokorelasi}

\begin{tabular}{|c|c|c|c|c|c|}
\hline \multicolumn{6}{|c|}{ Model Summary } \\
\hline Model & $\mathrm{R}$ & R Square & $\begin{array}{l}\text { Adjusted R } \\
\text { Square }\end{array}$ & $\begin{array}{l}\text { Std. Error of } \\
\text { the Estimate }\end{array}$ & $\begin{array}{l}\text { Durbin- } \\
\text { Watson }\end{array}$ \\
\hline 1 & $.748^{\mathrm{a}}$ & .559 & .489 & .10121 & 1.700 \\
\hline
\end{tabular}

Berdasarkan hasil uji diatas dihasilkan nilai DW 1,700 lebih besar menunjukan nilai DW sebesar 1,700 dari batas bawah (dl) 1,1426 dan pada taraf signifikan 0,05 dengan kurang dari 1,7386 (du) maka hasil variabel bebas adalah 4 dan $\mathrm{N}=30$, tidak dapat disimpulkan maka ditabel Durbin-Watson akan 


\section{Uji Koefisien Regresi berganda}

Coefficients $^{\mathrm{a}}$

\begin{tabular}{llrrrr}
\hline \multirow{2}{*}{ Model } & \multicolumn{3}{c}{$\begin{array}{c}\text { Standardized } \\
\text { Coefficients } \\
\text { Bnstandardized Coefficients }\end{array}$} \\
\hline 1 & B & Std. Error & Beta \\
& SIZE & -1.044 & .537 & & .333 \\
& ROA & .037 & .018 & -.163 \\
& TIPE & -.003 & .004 & .456 \\
SBS & .130 & .047 & .889 \\
\hline
\end{tabular}

a. Dependent Variable: ISR

1. Konstanta sebesar $>-1.044$ : sampel : sebesar -1,044 dimana variabel independen berada pada level konstan, yakni memiliki nilai yang sama dengan nol.

2. (SIZE) $>0,037 \quad$ : (SIZE) akan menaikkan Islamic Social Reporting sebesar 0,037, (SIZE),Profitabilitas (ROA), Tipe Industri (TIPE) ,Surat berharga syariah (SBS) dianggap konstan.

3. $($ ROA) $>-0.003$ : kenaikan satu satuan Profitabilitas (ROA) akan menurunkan Islamic Social Reporting sebesar 0,003,Ukuran perusahaan (SIZE), Profitabilitas (ROA), Tipe Industri (TIPE)
,Surat berharga syariah (SBS) dianggap konstan.

4. (TIPE) $>0,130:$ kenaikan satu satuan proporsi Tipe Industri (TIPE) akan menaikkan Islamic Social Reporting sebesar 0,130,Ukuran perusahaan (SIZE),Profitabilitas (ROA), Tipe Industri (TIPE) ,Surat berharga syariah (SBS) dianggap konstan

5. $(\mathrm{SBS})>0,165:$ setiap kenaikan satu Surat berharga Syariah (SBS) akan meningkatkan Islamic Social Reporting sebesar 0,165,Ukuran perusahaan (SIZE), Profitabilitas (ROA), Tipe Industri (TIPE) ,Surat berharga syariah (SBS) dianggap konstan . 


\section{Hasil Pengujian Hipotesis}

\begin{tabular}{|c|c|c|c|c|c|c|}
\hline \multicolumn{7}{|c|}{ Coefficients $^{\mathrm{a}}$} \\
\hline & \multirow[t]{2}{*}{ Model } & \multicolumn{2}{|c|}{$\begin{array}{l}\text { Unstandardized } \\
\text { Coefficients }\end{array}$} & \multirow{2}{*}{$\begin{array}{c}\text { Standardized } \\
\text { Coefficients } \\
\text { Beta }\end{array}$} & \multirow[t]{2}{*}{$\mathrm{T}$} & \multirow[t]{2}{*}{ Sig. } \\
\hline & & $\mathrm{B}$ & Std. Error & & & \\
\hline \multirow[t]{5}{*}{1} & (Constant) & -1.044 & .537 & & -1.944 & .063 \\
\hline & SIZE & .037 & .018 & .333 & 1.999 & .057 \\
\hline & ROA & -.003 & .004 & -.163 & -.977 & .338 \\
\hline & TIPE & .130 & .047 & .456 & 2.740 & .011 \\
\hline & SBS & .165 & .031 & .889 & 5.334 & .000 \\
\hline
\end{tabular}

a. Dependent Variable: ISR

Size: $t$ hitung 1,999 $t$ tabel : 1,69726 (yang ditetakn $0,057>0,05$ maka SIZE tidak berpengaruh terhadap ISR

ROA: $t$ hitung $-0,977 \mathrm{t}$ tabel 1,69726 (yang ditetapkan $0,338>0,05$ maka ROA tidak berpengaruh terhadap ISR
TIPE: $\mathrm{t}$ hitung 2,740 $\mathrm{t}$ tabel 1,69726 (yang ditetapkan $0,011<0,05 \quad$ maka TIPE berpengaruh terhadap ISR

SBS: $t$ hitung 5,334 $\mathrm{t}$ tabel $1,69726 \quad$ (yang ditetapkan $0,000<0,005$ maka SBS berpengaruh terhapat ISR

\section{PEMBAHASAN}

Pengaruh Ukuran Perusahaan (SIZE) Terhadap Islamic Social Reporting perusahaan yang terdaftar pada Indeks Saham Syariah Indonesia periode 20142016

Berdasarkan hasil pengujian hipotesis diketahui bahwa Ukuran Perusahaan (SIZE) tidak berpengaruh terhadap Islamic Social Reporting perusahaan yang terdaftar pada Indeks Saham Syariah Indonesia periode 2014-2016. Berdasarkan uji t didapatkan tingkat signifikan sebesar 0,057 lebih dari 0,05. Hal ini menyatakan bahwa Ukuran Perusahaan (SIZE) tidak berpengaruh terhadap Islamic Social Reporting Berdasar hasil uji diatas dapat disimpulkan bahwa hipotesis pertama $\left(\mathrm{H}_{1}\right)$ yaitu Ukuran Perusahaan(SIZE) berpengaruh terhadap Islamic Social Reporting yang terdaftar pada Indeks Saham Syariah Indonesia periode 2014-2016 adalah tidak diterima.

Hal ini dapat dijelaskan bahwa Ukuran perusaaan tidak berpengaruh terhadap ISR pada penelitian ini adalah semakin besar ukuran perusahaan biasanya informasi yang tersedia untuk investor dalam pengambilan keputusan semakin banyak, sehubungan dengan investasi dalam perusahaan tersebut. Semakin banyak perusahaan yang berukuran lebih besar biasanya memiliki lebih banyak tuntutan dari masyarakat terhadap informasi yang lebih tinggi dibanding perusahaan yang berukuran 
lebih kecil. Banyaknya pemegang saham menandakan jika perusahaan tersebut memerlukan lebih banyak pengungkapan yang dikarenakan adanya tututan dari pemegang saham dan dari para analisis pasar modal. (Anggraini, 2006). Ukuran perusahaan adalah karakteristik spesifik perusahaan yang hampir selalu digunakan untuk menguji tingkat pengungkapan sukarela (Othman, dkk., 2009).

Pengaruh Profitabilitas (ROA) Terhadap Islamic Social Reporting perusahaan yang terdaftar pada Indeks Saham Syariah Indonesia periode 2014-2016

Berdasarkan hasil pengujian hipotesis diketahui bahwa Profitabilitas (ROA) tidak berpengaruh terhadap Islamic Social Reporting perusahaan yang terdaftar pada Indeks Saham Syariah Indonesia periode 2014-2016. Berdasarkan uji t didapatkan tingkat signifikan sebesar 0.338 lebih dari 0,05 . Hal ini menyatakan bahwa Profitabilitas (ROA) tidak berpengaruh terhadap Islamic Social Reporting Berdasar hasil uji diatas dapat disimpulkan bahwa hipotesis kedua $\left(\mathrm{H}_{2}\right)$ yaitu Profitabilitas (ROA) berpengaruh terhadap Islamic Social Reporting yang terdaftar pada Indeks Saham Syariah Indonesia periode 2014-2016 adalah tidak diterima.

Hal ini dapat dijelaskan bahwa profitabilitas tidak berpengaruh terhadap ISR pada penelitian ini adalah Profitabilitas atau rentabilitas adalah menunjukkan kemampuan perusahaan untuk menghasilkan laba selama periode tertentu. Profitabilitas adalah kemampuan perusahaan untuk memperoleh keuntungan dari usahanya (Sunyoto, 2013).
Profitabilitas suatu perusahaan diukur dengan kesuksesan perusahaan dan kemampuan menggunakan aktivanya secara produktif, dengan demikian profitabilitas suatu perusahaan dapat diketahui dengan memperbandingkan antara laba yang diperoleh dalam suatu periode dengan jumlah aktiva atau jumlah modal perusahaan tersebut (Munawir, 2012).

Pengaruh Tipe Industri (TIPE) Terhadap Islamic Social Reporting perusahaan yang terdaftar pada Indeks Saham Syariah Indonesia periode 2014-2016

Berdasarkan hasil pengujian hipotesis diketahui bahwa Tipe Industri (TIPE) berpengaruh terhadap Islamic Social Reporting perusahaan yang terdaftar pada Indeks Saham Syariah Indonesia periode 2014-2016. Berdasarkan uji t didapatkan tingkat signifikan sebesar 0,011 lebih kecil dari 0,05 . Hal ini menyatakan bahwa Tipe Industri (TIPE) berpengaruh terhadap Islamic Social Reporting Berdasar hasil uji diatas dapat disimpulkan bahwa hipotesis ketiga $\left(\mathrm{H}_{3}\right)$ yaitu Tipe Industri (TIPE) berpengaruh terhadap Islamic Social Reporting yang terdaftar pada Indeks Saham Syariah Indonesia periode 2014-2016 adalah diterima ,

Hal ini dapat dijelaskan bahwa tipe industri berpengaruh terhadap ISR pada penelitian ini adalah tipe industri sesuai dengan teori legitimasi yaitu elastic mengakui bahwa bisnis dibatasi kontrak sosial yang menyebutkan bahwa perusahaan sepakat untuk menunjukan berbagai aktivitas social perusahaan agar perusahaan memperoleh penerimaan masyarakat akan tujuan perusahaan yang pada akhirnya menjamin kelangsungan hidup perusahaan, perusahaan manufaktur menghasilkan 
populasi yang lebih banyak dari pada perusahaan non manufaktur sehingga informasi tambahan harus diungkapkan dalam laporan tahunan perusahaan manufaktur. Cooke (dalam Gunawan, 2002) menyatakan bahwa luas pengungkapan dalam laporan tahunan mungkin tidak sama untuk semua sektor ekonomi. Menurut Verreccia (dalam Suripto, 2000) biaya proprietary (politik dan competitive disadvantage) berbeda antar industri. Disamping itu, menurut Meek, Robert dan Gray (dalam Suripto, 2000) relevansi item pengungkapan tertentu berbeda-beda antar industri.

\section{Pengaruh Surat berharga Syariah (SBS) Terhadap Islamic Social Reporting perusahaan yang terdaftar pada Indeks Saham Syariah Indonesia periode 2014- 2016}

Berdasarkan hasil pengujian hipotesis diketahui bahwa Surat berharga Syariah(SBS) berpengaruh terhadap Islamic Social Reporting perusahaan yang terdaftar pada Indeks Saham Syariah Indonesia periode 2014-2016. Berdasarkan uji t didapatkan tingkat signifikan sebesar 0,000 lebih kecil dari 0,05. Hal ini menyatakan bahwa Surat berharga Syariah(SBS) berpengaruh terhadap Islamic Social Reporting Berdasar hasil uji diatas dapat disimpulkan bahwa hipotesis empat $\left(\mathrm{H}_{4}\right)$ yaitu Surat berharga Syariah(SBS) berpengaruh terhadap Islamic Social Reporting yang terdaftar pada Indeks Saham Syariah Indonesia periode 2014-2016 adalah diterima ,

Hal ini dapat dijelaskan bahwa

Surat berharga syariah berpengaruh terhadap ISR pada penelitian ini adalah surat berharga syariah merupakan tambahan informasi yang dapat mempengaruhi keputusan stakeholder-nya. Tambahan informasi juga dibutuhkan sebagai salah satu bentuk monitoring pemegang sekuritas atas penggunaan dana. Seorang investor muslim pasti ingin mengetahui apakah dana yang mereka investasikan benar-benar digunakan untuk kegiatan yang tidak bertentangan syariah Islam. Dengan adanya tambahan informasi tersebut stakeholder dapat menilai kinerja suatu bank. Sehingga adanya surat berharga syariah dapat menghilangkan keraguan bagi para stakeholder-nya, Surat Berharga Syariah adalah sekuritas di pasar modal yang diterbitkan oleh perusahaan yang digunakan sebagai sumber pendanaan. Karina puri (2014).

\section{KESIMPULAN}

Berdasarkan hasil penelitian yang telah dilakukan, maka dapat ditarik beberapa kesimpulan yaitu:

1. Ukuran Perusahaan(SIZE) tidak berpengaruh terhadap Islamic Social Reporting perusahaan yang terdaftar pada Indeks Saham Syariah Indonesia periode 2014-2016

2. Profitabilitas (ROA) tidak berpengaruh terhadap Islamic Social Reporting perusahaan yang terdaftar pada Indeks Saham Syariah Indonesia periode 2014-2016.

3. Tipe Industri (TIPE) berpengaruh terhadap Islamic Social Reporting perusahaan 
yang terdaftar pada Indeks

Saham Syariah Indonesia periode 2014-2016.

4. Surat berharga Syariah(SBS) berpengaruh terhadap Islamic Social Reporting perusahaan yang terdaftar pada Indeks Saham Syariah Indonesia periode 2014-2016.

Penelitian memiliki beberapa keterbatasan antara lain : 1. Variabel penelitian dibatasi pada ukuran perusahaan, profitabilitas, tipe industri, Surat Berharga Syariah, dan Islamic Social Reporting perusahaan yang terdaftar pada Indeks Saham Syariah Indonesia periode 2014-2016. 2. Perhitungan ukuran perusahaan diproksikan dari total aset yang diperoleh dari laporan posisi keuangan pada akhir periode perusahaan dalam laporan tahunan perusahaan. Profitabilitas diproksikan dari nilai Return On Asset (ROA). Tipe industri dalam penelitian ini merupakan variabel dummy yang dikelompokkan ke dalam industri manufaktur dan non-manufaktur. Surat Berharga Syariah diukur kepemilikan jenis surat berharga syariah. Sedangkan Islamic Social Reporting dalam penelitian ini menggunakan Islamic Social Reporting Index. 3. Objek penelitian ini adalah perusahaan-perusahaan yang terdaftar pada Indeks Saham Syariah Indonesia (ISSI) dari tahun 2014 sampai dengan tahun 2016.

\section{SARAN}

1. Subjektifitas merupakan hal yang umum dihadapi dalam penelitian dengan metode content analysis. Dengan demikian, untuk mengurangi subjektifitas peneliti selanjutnya dapat berdiskusi dengan rekan sejawat, atau dengan peneliti lain yang pernah meneliti tentang pengungkapan indeks ISR.

2. Otoritas Jasa Keuangan (OJK) mengeluarkan daftar perusahaan yang memiliki efek atau sekuritas syariah, perusahaan yang masuk Daftar Efek Syariah (DES) ini dapat dijadikan sampel untuk penelitian selanjutnya.Namun, sebagian besar perusahaan yang masuk dalam DES belum memiliki visi misi berbasis syariah, sehingga hal ini nantinya akan menjadi suatu keterbatasan penelitian. Perusahaan yang masuk dalam DES seharusnya memiliki kesadaran dalam melakukan tanggung jawab sosial secara syariah, hal ini sebagai bentuk tanggung jawab perusahaan tersebut karena telah masuk dalam DES.

\section{DAFTAR PUSTAKA}

Awuy1, Vinta Yosefa Sayekti1, Indah Purnamawati1. 2013. Pengaruh Pengungkapn Corporate Social Responsibility (CSR) Terhadap Earnings Response Coefficient (ERC) (Suatu Studi Empiris Pda Perusahaan Pertambangan 
yang Terdaftar di Bursa Efek Indonesia Pada Tahun 20102013) jurnal CSR hal 17

Anggraini, Fr. Reni Retno. 2006. Pengungkapan Informasi Sosial dan Faktor-faktor yang Memepngaruhi Pengungkapan Informasi Sosial dalam Laporan Keuangan Tahunan (Studi Empiris Pada PerusahaanPerusahaan Yang Terdaftar Pada Bursa Efek Jakarta). Simposium Nasional Akuntansi IX. Padang, 23-26 Agustus. hal. $1-21$.

Sugiyono, 2013. Metode Penelitian Manajemen. ALFABETA : Bandung.

Brigham, Eugene F. dan Houston, Joel. F. 2010. Dasar-Dasar Manajemen Keuangan. Penerjemah: Ali Akbar Yulianto. Jakarta: Salemba Empat.

Fahmi, Irham. 2014. Manajemen Keuangan Perusahaan dan Pasar Modal. Jakarta: Mitra Wacana Media.

Fauziah, Khusnul dan Jayanto, Prabowo Yudho. 2013. Analisis Pengungkapan Tanggungjawab Sosial Perbankan Syariah di Indonesia Berdasarkan Islamic Social Reporting Indeks. Jurnal Dinamika Akuntansi. Nol. 5. No. 1. hal. 12-20.

Fitria, Soraya dan Hartanti, Dwi. 2010. Studi Perbandingan Pengungkapan Berdasarkan Global Reporting Initiative Indeks dan Islamic Social Reporting Indeks. Simposium Nasional Akuntansi. Purwokerto. Proceeding.

Ghozali, Imam. 2016. Aplikasi Analisis Multivariate dengan Program IBM SPSS 23.
Semarang: Badan Penerbit Universitas Diponegoro.

Halim, Abdul. 2007. Analisis Investasi. Jakarta: Salemba Empat.

Hariandy, P. 2011. Analisis Pengaruh Struktur Kepemilikan, Tingkat Diversifikasi dan Dana Pihak Ketiga terhadap Tingkat Pengungkapan Sukarela. Skripsi. Depok: Fakultas Ekonomi Universitas Indonesia.

Iqbal, Zamir dan Abbas Mirakhor. 2008. Pengantar Keuangan Islam Teori dan Praktik. Jakarta: Fajar Interpratama Offset.

Kasmir. 2008. Analisis Laporan Keuangan. Jakarta: Raja Grafindo Persada.

Margaretha, Farah dan Ramadhan, Aditya Rizky. 2010. Faktorfaktor yang Mempengaruhi Struktur Modal pada Industri Manufaktur di Bursa Efek Indonesia. Jurnal Bisnis dan Akuntansi. Vol. 12, No. 2. hal. 119-130.

Mulianti, Fitri Mega. 2010. Analisis Faktor-Faktor yang Mempengaruhi Kebijakan Hutang dan Pengaruhnya terhadap Nilai Perusahaan. Tesis. Semarang: Fakultas Ekonomi UNDIP.

Novrizal, Muhammad Fajrul dan Fitri, Meutia. 2016. FaktorFaktor yang Mempengaruhi Pengungkapan Corporate Social Responbility (CSR) pada Perusahaan yang Terdaftar di Jakarta Islamic Index (JII) tahun 2012-2015 dengan Menggunakan Islamic Social Reporting (ISR) Index sebagai Tolok Ukur. Jurnal Ilmiah Mahasiswa Ekonomi Akuntansi 
(JIMEKA). Vol. 1. No. 2. hal. 177-189.

Othman, Rohaha; Thani, Azlan Md.; dan Ghani, Erlane K. 2009. Determinants of Islamic Social Reporting Among Top ShariaApproved Companies in Bursa Malaysia. Research Journal of International Studies. Issue 12. pp. 4-20..

Purnasiwi, Jayanti. 2011. Analisis Pengaruh Size, Profitabilitas dan Leverage terhadap Pengungkapan CSR pada Perusahaan yang terdaftar di Bursa Efek Indonesia. Skripsi. Semarang: Fakultas Ekonomi UNDIP.

Putri, Tria Karina dan Yuyetta, Etna Nur Afri. 2014. Faktor-Faktor yang Mempengaruhi Islamic Social Reporting PerusahaanPerusahaan yang Terdaftar Pada Indeks Saham Syariah Indonesia (ISSI) Tahun 20112012. Diponegoro Journal of Accounting. Vol. 3. No. 2. hal. 1-9.

Putri, Tria Karina. 2014. FaktorFaktor yang Mempengaruhi Islamic Social Reporting Perusahaan-Perusahaan yang Terdaftar pada Indeks Saham Syariah Indonesia Tahun 20112012. Skripsi. Semarang: Universitas Diponegoro.

Raditya, Amilia Nurul. 2012. Analisis

Faktor-Faktor yang Mempengaruhi Tingkat Pengungkapan Islamic Social
Reporting (ISR) Pada Perusahaan yang Masuk Daftar Efek Syariah (DES). Skripsi. Depok: Fakultas Ekonomi Prodi Akuntansi Universitas Indonesia.

Sugiyono. 2013. Metode Penelitian Kuantitatif, Kualitatif, dan $R \& D$. Bandung: Alfabeta.

Sujoko dan Soebiantoro, Ugy. 2007. Pengaruh Struktur Kepemilikan, Leverage, Faktor Intern, dan Faktor Ekstern terhadap Nilai Perusahaan (Studi Empirik pada Perusahaan Manufaktur dan Non Manufaktur di Bursa Efek Jakarta). Jurnal Manajemen dan Kewirausahaan, Vol. 9. No. 1. hal. 41-48.

Sunyoto, Danang. 2013. Analisis Laporan Keuangan untuk Bisnis (Teori dan Kasus). Jakarta: Buku Seru.

Widiawati, Septi dan Raharja, Surya. 2012. Analisis Faktor-Faktor yang Mempengaruhi Islamic Social Reporting PerusahaanPerusahaan Yang Terdapat Pada Daftar Efek Syariah Tahun 2009-2011. Diponegoro Journal of Accounting. Vol. 1. No. 2. hal. 1-15.

Yuliati, Ani. 2011. Faktor-Faktor yang Berpengaruh Pada Audit Delay (Studi empiris pada Perusahaan Manufaktur yang Terdaftar di BEI tahun 20072008). Skripsi. Yogyakarta: FISE UNY. 